UDC 541.13.544.65

\title{
STUDY OF ELECTRODEPOSITION OF NICKEL FROM ALKALINE GLYCINE ELECTROLYTES
}

\author{
N.R.Abıshova, G.S.Aliyev, U.M.Gurbanova, Y.A.Nuriyev, S.A.Huseynova \\ M.Nagiyev Institute of Catalysis and Inorganic Chemistry, NAS of Azerbaijan \\ nurayabisova@gmail.com
}

Received 28.04.2021

Accepted 01.06.2021

\begin{abstract}
The essay is about studies of the electrochemical reduction of nickel ions from a glycine electrolyte by the method of recording cyclic and linear potentiodynamic polarization curves. The effect of the concentration of the main components, potential sweep and temperature on the electrodeposition process of nickel has been studied. It has been found that at the beginning of the process the electrodeposition of the nickel ions from glycine electrolyte is controlled by electrochemical polarization, which turns into concentration polarization.
\end{abstract}

Keywords: nickel, electrodeposition, glycine, polarization.

doi.org/10.32737/0005-2531-2021-4-20-24

\section{Introduction}

Nickel is one of the most used metals in the galvanic deposition process (electroplating) because of its high corrosion resistance and hardness. It is used in a wide-ranging applications - in mechanical engineering, aerospace industry and electronics [1,2]. Due to their high hardness and resistance to tarnishing, they have been an alternative to galvanized chromium in the manufacture of accessories for electronic equipment and cars [3].

Nickel electrodeposition has been studied by many researchers with various electrolytes using various additives $[4,5]$.

In [6], the effect of the electrolyte composition and electrolysis conditions on the properties of thin nickel films obtained on the surface of a steel disk electrode by the pulsed deposition method from sulfamate electrolytes has been studied. Electrolysis was carried out at 315 $\mathrm{K}$ temperature from a nickel sulfamate electrolyte with a concentration of $0.994 \mathrm{M}$, and rotational speed of the disk electrode was $500 \mathrm{rpm}$ (r/min). It was found that the electrodeposition process of nickel is controlled by the diffusion of its own ions to the electrode surface.

The authors of [7] investigated the reduction of nickel ions from Watt's electrolyte and came to the conclusion that the process occurs in three stages: 1 - chemical reaction preceding the electrochemical reaction, 2 - begin- ning of the surface reactions with adsorption of intermediate products and 3 -diffusion of electroactive substances to the electrode. This nickel deposition mechanism is considered to be the most relevant.

It is known that the presence in the electrolyte of additives, such as complexing and surfactant compounds beneficially effects on the deposition process. Thus, in [8], the effect of thiourea on the current efficiency (Faraday efficiency), the quality of the deposited films, the crystal structure and surface morphology during the electrodeposition of nickel from acidic sulfate solutions was studied. The electrolysis lasted for 2 hours at a temperature of $60^{\circ} \mathrm{C}$. It was found that an increase in the concentration of thiourea from 2 to $40 \mathrm{mg} / \mathrm{L}$ insignificantly (3-4\%) reduces the current efficiency of nickel. The quality and morphology of the surface of nickel films deteriorated significantly at higher concentrations of thiourea, the deposits were contaminated with impurities. Xray phase analysis showed that the presence of thiourea in the electrolyte increased the intensity of the peaks of the crystalline planes of the deposits, i.e. the crystallinity of the deposits increased.

Shiny nickel films have been obtained on the surface of copper substrates by electrodeposition process from acidic glycine electrolytes [9]. The properties of the films were 
investigated using electron spectroscopy, potentiodynamic cathodic polarization, cyclic voltammetry, chronoamperometry, supplemented by Xray diffraction analysis and SEM measurements. Kinetic parameters such as Tafel slope, transfer coefficient and exchange current density obtained from Tafel curves indicate that glycine has an accelerating effect on electroreduction of $\mathrm{Ni}^{2+}$ ions. The corrosion behavior of nickel films has been studied using anodic potentiodynamic polarization and open-circuit potential in $3.5 \% \mathrm{NaCl}$ solution. The results showed that the presence of glycine in the electrolyte reduces the corrosion resistance of the deposited nickel coatings.

The use of glycine in the electrodeposition of metals and alloys contributes to the stabilization of the $\mathrm{pH}$ of the electrolyte due to its high buffering properties, serves as a complexing agent and is environmentally safer than other electrolytes of nickel-plating. Electrodeposition from glycine electrolytes contributes to the obtaining of amorphous deposits with a high current efficiency $[10,11]$.

The stability of complexation between divalent ions of transition metals and glycine peptides has been studied at a temperature of $298.15 \mathrm{~K}$ in aqueous solution with an ionic strength of $0.15 \mathrm{~mol} / \mathrm{dm}^{3}$ of $\mathrm{NaNO}_{3}$. The values of the stability constants of the nickel-glycine complexes have been determined from the $\mathrm{pH}$ potentiometric data [12].

This work presents the results of studies about the electrodeposition of nickel from glycine electrolytes to use the data obtained in the codeposition of thin Co-Ni films from the same electrolyte with magnetic properties and to study the possibility of using these films as electrocatalysts in the water splitting reaction. During the experiments, the effect of nickel concentration, potential sweep rate and temperature on the reduction process of nickel ions from glycine electrolytes has been investigated.

\section{Experimental part}

When studying the electrochemical deposition of nickel from an alkaline glycine electrolyte, the required amount of nickel sulfate has been dissolved in a glycine solution. Linear and cyclic polarization curves have been recorded on an IVIUMSTAT Electrochemical Interface potentiostat using a classic $100 \mathrm{ml}$ three-electrode cell, equipped with a water jacket. The working electrodes were a platinum wire with an area of $3 \cdot 10^{-3} \mathrm{dm}^{2}$, a platinum plate with an area of 0.04 $\mathrm{dm}^{2}$ was used as an auxiliary electrode, and a silver chloride electrode was used as a reference electrode. During electrochemical nickel-plating, an alkaline glycine electrolyte has been used, which was prepared by dissolving glycine in distilled water, the concentration of glycine was $1.5 \mathrm{M}$, then a calculated amount of $\mathrm{NiSO}_{4} \cdot 6 \mathrm{H}_{2} \mathrm{O}$ has been added into the solution. By adding $\mathrm{NaOH}$ to the solution, the $\mathrm{pH}$ of the electrolyte has been brought to 10 and polarization curves have been recorded.

When studying the temperature dependence of the polarization curves, the temperature in the electrolyzer has been held constant using a universal UTU-4 ultrathermostat.

\section{Results and discussion}

Glycine $\left(\mathrm{H}_{2} \mathrm{~N}-\mathrm{CH}_{2}-\mathrm{COOH}\right)$ is usually considered as a dipole ion, the structure of which protonates or deprotonates depending on the $\mathrm{pH}$ of the solution [13] and the equilibrium between them is shown in equation (1).

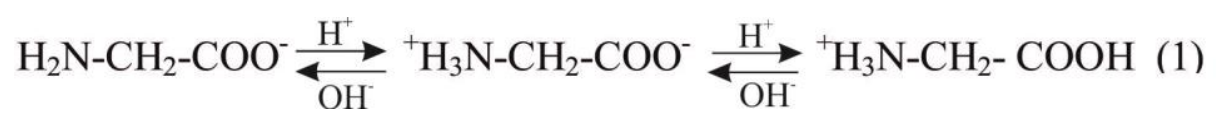

The nickel complexes present in the electrolyte have a different form depending on the ratio of the concentrations of $\mathrm{Ni}^{2+}$ to glycine and on the $\mathrm{pH}$ of the electrolyte. At higher $\mathrm{pH}$ values $(8-10), \mathrm{Ni}^{2+}$ exists mainly in the form of $\left[\mathrm{NiGly}_{3}\right]^{-}$ with a high value of the stability constant [14]:

$$
\begin{aligned}
& \mathrm{Ni}^{2+}+\mathrm{Gly}^{-} \leftrightarrow[\mathrm{NiGly}]^{+} \\
& \mathrm{Ni}^{2+}+2 \mathrm{Gly}^{-} \leftrightarrow\left[\mathrm{NiGly}_{2}\right] \\
& \mathrm{Ni}^{2+}+3 \mathrm{Gly}^{-} \leftrightarrow\left[\mathrm{NiGly}_{3}\right]^{-}
\end{aligned}
$$

Consequently, in the investigated glycine electrolyte at $\mathrm{pH}=10$, nickel is present in the 
form of a complex ion $\left[\mathrm{NiGly}_{3}\right]^{-}$. Figure 1 shows a cyclic polarization curve for the reduction of nickel ions from an alkaline glycine solution containing $0.1 \mathrm{M} \mathrm{NiSO}_{4} \cdot 6 \mathrm{H}_{2} \mathrm{O}$.

It is seen from figure 1 that the reduction of nickel begins at a potential of $\sim-0.23 \div-0.28$ V. Anodic dissolution of nickel occurs in one stage at a potential of $-0.55 \mathrm{~V}$, in contrast to the data obtained in the study of the deposition of nickel from ammonium electrolytes of the Watt type in the absence of glycine, where dissolution occurs in two stages [15].

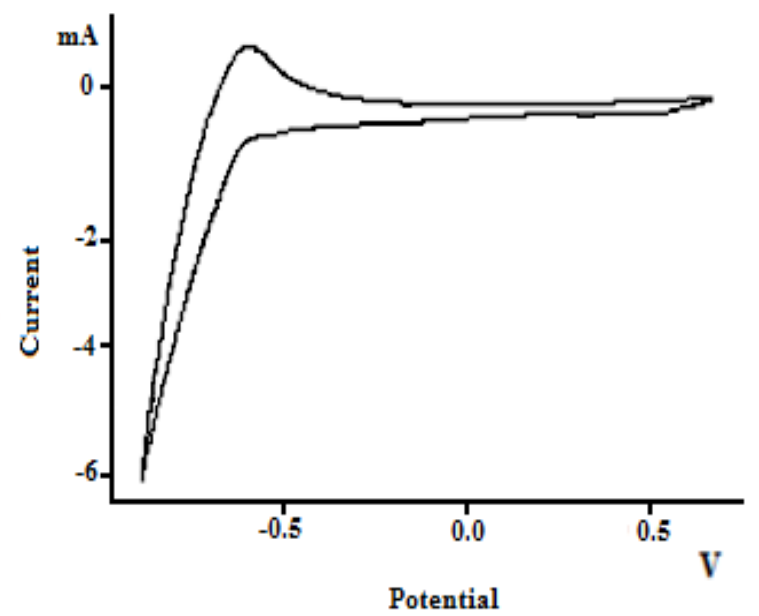

Fig.1. Current-voltage polarization curve of the reduction of nickel ions from an alkaline glycine electrolyte on a platinum electrode. Electrolyte composition: $0.1 \mathrm{M} \mathrm{Ni}$ $\mathrm{SO}_{4} \cdot 6 \mathrm{H}_{2} \mathrm{O}, 1.5 \mathrm{M}$ Glycine, $\mathrm{pH}=10, \mathrm{E}_{\mathrm{v}}=0.06 \mathrm{~V} / \mathrm{s}, \mathrm{T}=298 \mathrm{~K}$.

The electrodeposition of nickel in glycine solutions at the concentration of $0.1 \mathrm{M}$ of $\mathrm{NiSO}_{4} \cdot 6 \mathrm{H}_{2} \mathrm{O}$ occurs at a potential of $-0.65 \mathrm{~V}$, most likely simultaneously with the hydrogen release process according to reaction (5):

$\left[\mathrm{NiGly}_{3}\right]^{-}+2 \mathrm{e}^{-}=\mathrm{Ni}+3 \mathrm{NH}_{2} \mathrm{CH}_{2} \mathrm{COO}^{-}$

The potentiodynamic curve of the cathodic polarization of nickel at a high $\mathrm{pH}$ value $(\mathrm{pH}$ $=10)$ is noticeably shifted to the negative values.

The volt-ampere curves of the reduction of nickel ions in its various concentrations in the electrolyte are presented in Figure 2. With an increase in the concentration of nickel, the reduction potential of its ions shifts to the positive side. At $\mathrm{NiSO}_{4} \cdot 6 \mathrm{H}_{2} \mathrm{O}$ concentrations of $0.3 \div 0.8 \mathrm{M}$, the reduction of nickel begins at a potential of $-0.42 \mathrm{~V}$, whereas at low nickel concentrations $(0.1 \mathrm{M})$, the reduction occurs at a potential of $-0.72 \mathrm{~V}$ simultaneously with the hydrogen release.

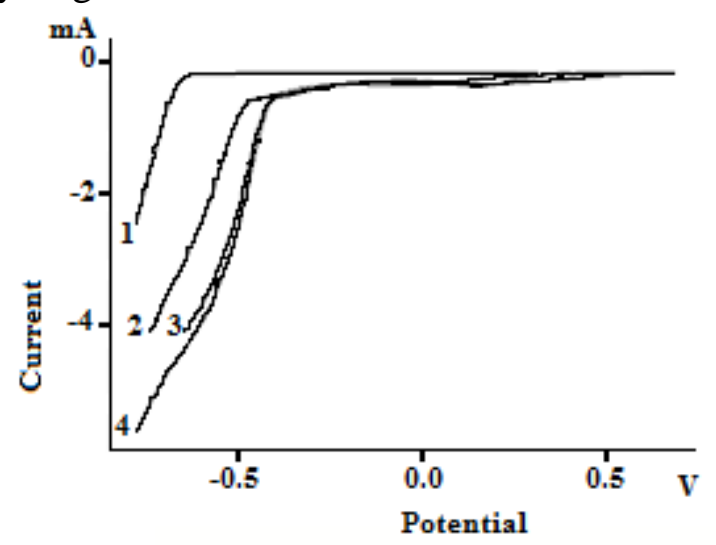

Fig.2. Current-voltage curves of nickel reduction from an alkaline glycine electrolyte on the platinum electrode in its different concentrations in the electrolyte. Electrolyte Composition (M): Glycine $1.5 \mathrm{M}, \mathrm{NiSO}_{4} \cdot 6 \mathrm{H}_{2} \mathrm{O}: 1-0.1$, $2-0.3,3-0.5,4-0.8, \mathrm{E}_{\mathrm{v}}=0.1 \mathrm{~V} / \mathrm{s}, \mathrm{pH}=10, \mathrm{~T}=298 \mathrm{~K}$.

The effect of the potential sweep rate on nickel electrodeposition has been investigated. The potential sweep was varied in the range of $0.005 \div 0.1 \mathrm{~V} / \mathrm{s}$.

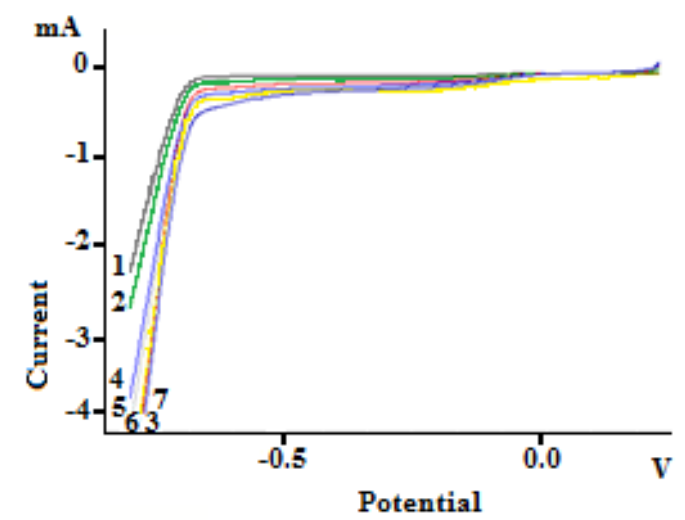

Fig.3. The effect of the potential sweep rate on the deposition of nickel from an alkaline glycine electrolyte on the surface of a platinum electrode. Electrolyte composition (M): $\mathrm{NiSO}_{4} \cdot 6 \mathrm{H}_{2} \mathrm{O}-0.1 ; \mathrm{H}_{2} \mathrm{~N}-\mathrm{CH}_{2}-\mathrm{COOH}-1.5 ; \mathrm{T}=298 \mathrm{~K}$, $\mathrm{pH}=10, \mathrm{v}, \mathrm{V} / \mathrm{s}: 1-0.005,2-0.01,3-0.2,4-0.04,5-$ $0.06,6-0.08,7-0.1$.

As the potential sweep rate increases, the rate of cathodic process increases, and the nickel reduction potential shifts towards positive potentials. Based on the data shown in Figure 3, the dependence of $i_{p}$ on $v^{1 / 2}$ was plotted (Figure 4). The processing of the obtained data in coordinates of $\mathrm{i}_{\mathrm{p}}$ and $v^{1 / 2}$ showed that this dependence is linear. This dependence is typical for processes controlled by concentration polarization [16]. 


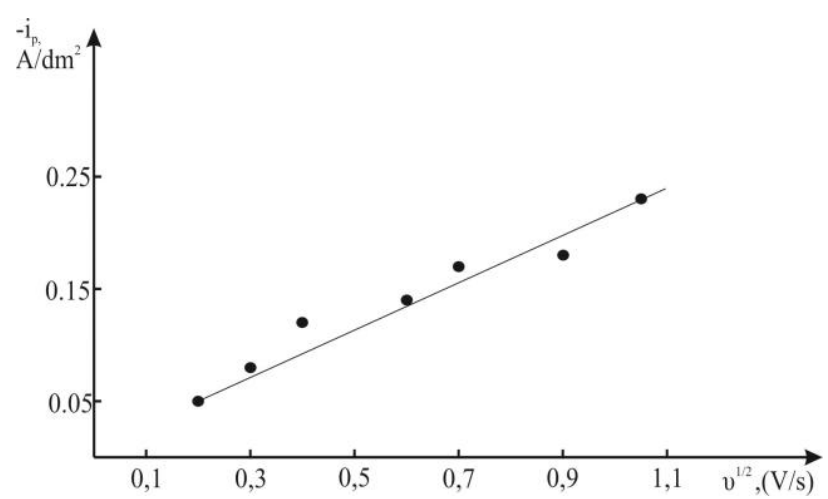

Fig.4. Dependence of $i_{p}$ on $v^{1 / 2}$ for the deposition process of nickel from alkaline glycine electrolytes, electrolyte composition (M): $\mathrm{NiSO}_{4} \cdot 6 \mathrm{H}_{2} \mathrm{O}-0.1, \mathrm{H}_{2} \mathrm{~N}-\mathrm{CH}_{2}-\mathrm{COOH}$ $-1.5, \mathrm{pH}=10$.

The effect of the temperature on the reduction of nickel ions has been investigated to test this version. During the study, the temperature of the electrolyte has been changed in the range of 298-333 K. With increasing temperature, the rate of cathodic reduction of nickel ions increases and the deposition potential slightly shifts to the positive side (Figure 5).

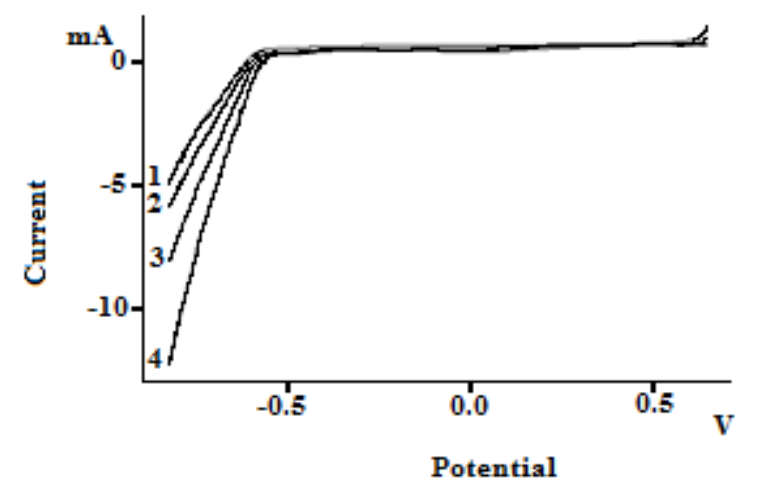

Fig.5. The effect of the temperature on the deposition process of nickel from an alkaline glycine electrolyte on a platinum electrode. Electrolyte composition (M): $\mathrm{NiSO}_{4}$. $6 \mathrm{H}_{2} \mathrm{O}-0.1, \mathrm{H}_{2} \mathrm{~N}-\mathrm{CH}_{2}-\mathrm{COOH}-1.5, \mathrm{pH}=10, \mathrm{v}=0.1 \mathrm{~V} / \mathrm{s}$, $\mathrm{T}(\mathrm{K})=1-298,2-308,3-323,4-333$.

According to the Figure 5, the dependence of the logarithm of the current density (lgi) on the inverse temperature value $(1 / \mathrm{T})$ has been plotted at the various values of the cathodic potential to determine the nature of polarization during the deposition of nickel from alkaline glycine electrolytes. In Figure 6, the dependence lgi-1/T is shown in the range of cathode potentials of $0.45-0.525 \mathrm{~V}$, from which it is seen that this dependence is linear at all potential values. It is seen from the figure that at higher potentials $(0.5-0.525 \mathrm{~V})$, the slope of the line segments is greater than at potentials of $0.4-0.475 \mathrm{~V}$.

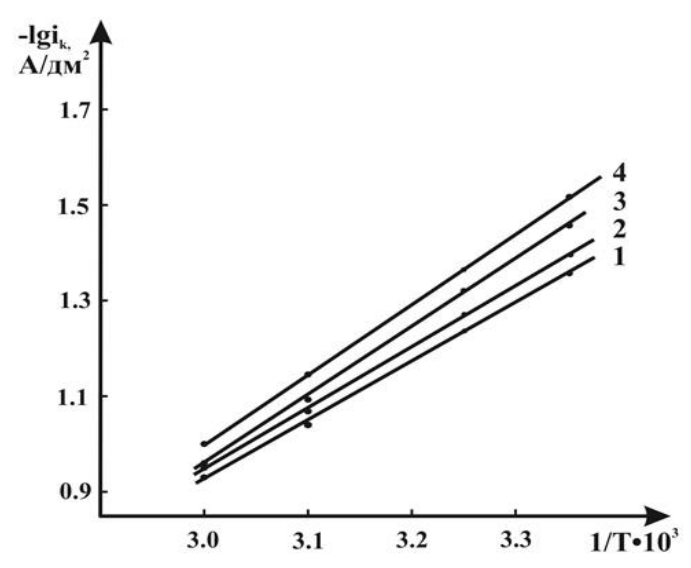

Fig.6. The dependence of the current density on the temperature at various potentials $\mathrm{E}_{\mathrm{c}}(\mathrm{V}): 1-0.525,2-0.5,3$ $-0.475,4-0.45$.

According to the slopes of the line segments, the value of the activation energy has been determined by the formula (6):

$$
\mathrm{A}_{\mathrm{eff}}=-2.3 \mathrm{R} \operatorname{tg} \alpha
$$

The dependence of $\mathrm{A}_{\text {eff }}$ on the cathode potential is shown in Figure 7. In the range of cathodic potentials from $0.45 \mathrm{~V}$ to $0.525 \mathrm{~V}$, the activation energy slips sharply from $31 \mathrm{~kJ} / \mathrm{mol}$ to $24 \mathrm{~kJ} / \mathrm{mol}$, then the value of the activation energy decreases insignificantly; the curve goes on almost parallel to the axis of abscissa. In other words, the process of cathodic reduction of nickel is initially controlled by electrochemical polarization, which turns into concentration polarization.

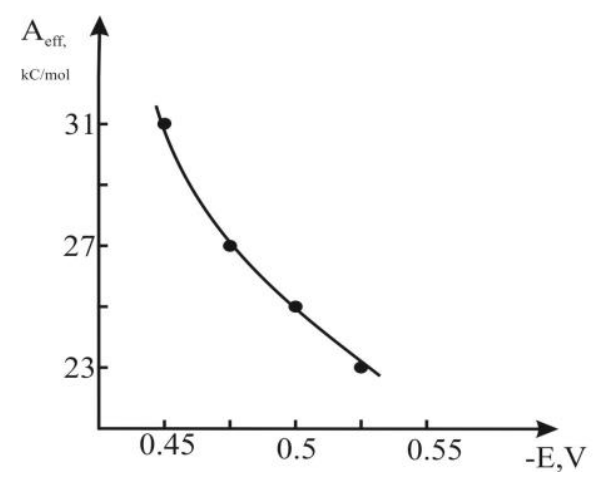

Fig.7. The dependence of the effective activation energy $A_{\text {eff }}$ on $E_{v}$.

Thus, we can conclude that the concentration of nickel ions in the solution and the 
temperature of the electrolyte effect on the process of reduction of nickel ions in an alkaline glycine electrolyte; and the process itself are controlled by electrochemical polarization, which turns into concentration polarization.

\section{References}

1. Mohanty U.S., Tripathy B.C., Singh P., Das S.C. Effect of $\mathrm{Cd}^{2+}$ on the electrodeposition of nickel from sulphate solutions. Part I: Current efficiency, surface morphology and crystal orientations. J. Electroanal. Chem. 2002. V. 526. No 1-2. P. 63-68.

2. Orinakova R., Turonova A., Kladekova D., Galova M., Smith R.M. Recent developments in the electrodeposition of nickel and some nickel-based alloys. J. Appl. Electrochem. 2006. V. 36. No 63. P. 957-972.

3. Ibrahim M.A.M., Abd El Rehim S.S., Abd El Wahaab S.M., Dankeria M.M. Nickel electroplating on steel from acidic citrate baths. Plat. Surf. Finish. 1999. V. 86. No 4. P. 69-75.

4. Taranina O.A., Evreinova N.V., Shoshina I.A., Naraev V.N., Tikhonov K.I. Electrodeposition of nickel from sulfate solutions in the presence of aminoacetic acid. Russ. J. Appl. Chem. 2010. V. 83. No 1. P. 58-61.

5. Lee a J., Chung W., Jung U., Kim Y. Direct nickel electrodeposition on magnesium alloy in pyrophosphate electrolyte. Surf. Coat. Technol. 2011. V. 205. No 16. 1 P. 4018-4023.

6. Halmdienst M., Hansal W. E. G., Kaltenhauser G., Kautek W. Pulse plating of nickel: influence of electrochemical parameters and compositionof electrolyte. The Int. J. Surface Engineering and Coatings. 2007. V. 85. No 1. P. 22-26.

7. Supicova M., Rozik R., Trnkova L., Orinakova R., Galova M. Influence of boric acid on the electrochemical deposition of Ni. Solid State Electrochem. 2006. V. 10. No 2. P. 61-68.

8. Mohanty U.S., Tripathy B.C., Das S.C., Misra V.N. Effect of thiourea during nickel electrodeposition from acidic sulfate solutions. Metallurgical and Materials Transactions B. 2005. V. 36. No 6. P. 737-774.

9. Ibrahim M.A.M., Rasha Al Radadi M. Role of Glycine as a Complexing Agent in Nickel Electrodeposition from Acidic Sulphate Bath. Int. J. Electrochem. Sci. 2015. V.10. P. 4946-4971.

10. Evreinova N.V., Shoshina I.A., Naraev V.N., Tikhonov K.I. Electrodeposition of iron from sulfate solutions in the presence of aminoacetic acid. Russ. J. Appl. Chem. 2008. V. 81. P. 1180-1183.

11. Lačnjevac U., Jović B. M., Jović V.D. Electrodeposition of $\mathrm{Ni}, \mathrm{Sn}$ and $\mathrm{Ni}-\mathrm{Sn}$ Alloy Coatings from Pyrophosphate-Glycine Bath. J. Electrochem. Soc. 2012. V. 159. No 5. P. 310-318.

12. Angkawijaya A.E., Fazary A.E., Ismadji S., Ju Y.H. $\mathrm{Cu}(\mathrm{II}), \mathrm{Co}(\mathrm{II})$, and $\mathrm{Ni}(\mathrm{II})-$ Antioxidative Phenolate-Glycine Peptide Systems: An Insight into Its Equilibrium Solution Study. J. Chemical \& Engineering Data. 2012. V. 57. No 12. P. 3443-3451.

13. Schwartz M., Myung N.V., Nobe K. Electrodeposition of Iron Group-Rare Earth Alloys from Aqueous Media. J. Electrochim. Soc. 2004. V. 151. No 7. P. 468-477.

14. Sotskaya N.V., Dolgikh O.V. Nickel electroplating from glycine containing baths with different pH. J. Prot. Met. 2008. V. 44. No 5. P. 479-486.

15. Kurbanova U.M. Elektroosazhdeniye nikelya iz ammiachnogo elektrolita. Azərbaycan Milli Elmlər Akademiyası Naxçıvan Bölməsinin Elmi əsərləri. Təbiət və texniki elmlər seriyası. 2019. No 2. P. 60-67.

16. Galyus S.V. Teoreticheskiye osnovy elektrokhimicheskogo analiza. M.: 1974, 532 s.

\section{NIKELIN QəLӘVI QLISIN ELEKTROLITLəRINDӘN ELEKTROÇÖKDÜRÜLMəSININ TəDQIQI N.R.Abışova, Q.S.Oliyev, Ü.M.Qurbanova, Y.A.Nuriyev, S.A. Hüseynova}

Məqalədə tsiklik və xətti potensiodinamik polyarlaşma əyrilərinin çəkilməsi yolu ilə nikel ionlarının qlisin elektrolitlərindən elektrokimyəvi reduksiyasının tədqiqi verilmişdir. Nikelin elektroçökdürülmə prosesinə əsas komponentlərin konsentrasiyasının, potensialın dəyişmə sürətinin və temperaturun təsiri öyrənilmişdir. Müəyyən olunmuşdur ki, nikel ionlarının qlisin elektrolitindən elektroçökdürülmə prosesi qatılıq polyarlaşması ilə idarə olunur.

Açar sözlor: nikel, elektroçökdürmo, qlisin, polyarizasiya

\section{ИССЛЕДОВАНИЕ ЭЛЕКТРООСАЖДЕНИЯ НИКЕЛЯ ИЗ ЩЕЛОЧНЫХ ГЛИЦИНОВЫХ ЭЛЕКТРОЛИТОВ}

\section{Н.Р.Абышова, Г.С.Алиев, У.М.Курбанова, Ю.А.Нуриев, С.А.Гусейнова}

В работе приведены исследования электрохимического восстановления ионов никеля из глицинового электролита методом снятия циклических и линейных потенциодинамических поляризационных кривых. Изучено влияние концентрации основных компонентов, развертки потенциала и температуры на процесс электроосаждения никеля. Установлено, что процесс электроосаждении ионов никеля из глицинового электролита в начале процесса контролируется электрохимической поляризацией, переходящей в концентрационную.

Ключевые слова: никель, электроосаждения, глиџин, поляризаџия. 